\title{
8 Revitalization: Living Lab as a format for accelerating energy transition in Polish rural areas
}

\author{
The case studies of metropolitan outskirts \\ of Gdańsk-Orunia and Lubań
}

\author{
Bartosz Pietrzykowski, Gabriela Rembarz and \\ Adam Cenian
}

\section{Introduction}

The collapse of the socialistic regime in Poland revealed the need for revitalization of neglected regions. Later, the neoliberal paradigm of the country's socio-economic development posed numerous challenges, in terms of the energy transformation that is broadly understood as a necessary change in the lifestyle of European society. The scope of this transformation should involve constructive social dialogue, which allows, firstly, identification of reliable and committed stakeholders, secondly, to develop public trust and, consequently, gain the local community's acceptance for modernization. Analyzing the changes emerging during the last three decades of continuous system transformation, one observes certain phases of city planning and management development, which are essential for energy transition:

- Phase of Decay (1978-1989): loss of confidence in public planning and management, so called centrally planned economy and growing demand for infrastructure modernization;

- Phase I System Transition (1990-1994): development of new economic system and principles for state based on self-government under strong social support and unstable economy; adoption of neoliberal paradigm in city planning and management;

- Phase II Radical Management Overhaul (1995-2004): restructuring of communal entities management; privatizing of public services and energy market; initiation of modernization processes under dynamic growth of building market; suburbanization; priority for large cities development and regress of rural areas;

- Phase III Stabale Modernization Process (2004-2015): adaptation of EU standards and policy supported by structural funds; implementation of large key projects defined as civilization leap, enabling entry to the developed country circle (e.g., FTSE Russell ${ }^{1}$ ); growing social polarization resulting 
from neoliberal reforms and globalization; growing public distrust under increasing civic and ecological awareness;

- $\quad$ Phase IV New reforms (from 2016): superficially pro-social systemic changes inhibiting modernization processes and economic development; growth of public awareness related to ecology and social responsibility; detrimental conditions for energy transition.

The dysfunctional planning system, in which the public sector is not a strong player in terms of urban space quality and lack of a modern legal framework that would address the operation of local governments, inhibit the development of effective participatory planning and the implementation of contemporary organizational solutions based on public-private partnership. This not only significantly obstructs the development of high-quality compact cities, but also effectively supports irrational space management. The escalation of suburbanization (NIK, 2017) as well as the fact that public support for the revitalization processes has been delayed by two decades, including the related socio-political and legal gaps (Przywojska, 2016), are the main reasons behind the lack of a systemic solution to the issue of thermal modernization in urban structures, which has been a significant challenge for all European countries indiscriminately. Development of such methods of action as Revitalization: Living Lab (R_LL) and others, which enable effective acceleration of city revitalization, along with energy transition, has therefore become increasingly important (Rembarz, 2018d; Cenian et al., 2019).

The Princeton's WordNet dictionary defines revitalization as the "bringing again into activity and prominence," while the Cambridge dictionary additionally characterizes it as "the process of making something grow, develop, or become successful again." 3 So, urban revitalization takes into account aspects of social, urban-infrastructure and economic challenges, and its activities are aimed at reversal of the negative trends (Revitalization Act, 2015). It encompasses modification of energy, and other infrastructure, but is not limited to technical issues. It also involves consideration of the local people's well-being and should entail the local community's participation.

This chapter aims to present the experience gained from the cooperation under an informal format of R_LL, against the background of the conditions underlying the implementation of energy transformation in Poland. The R_LL implemented under the rural and semi-rural conditions of the metropolitan fringes of Gdańsk should be considered as an alternative to the routine practices of local administration and politics, which are quite cautious when it comes to the risk of experimenting with and implementing progressive changes (Dziemianowicz and Szlachta, 2016). The development of R_LL, under the voluntary cooperation of local entrepreneurs and/or urban activists together with the representatives of the local community and the scientific community, enables feedback transfer of knowledge and experience. The thermomodernization thread embedded in the revitalization carried out as a bottom-up activity strengthens the catalytic effect of the change process. It not only becomes the carrier of technological change, but also a factor supporting the development of social capital. 
Energy transformation, understood as the change in the lifestyle of individuals and communities, requires special catalyzing solutions that take into account the importance of the social dimension, in terms of the technological change introduced. Community involvement is crucial when the level of social trust is low, which is a characteristic of public-life relations in young democracies, such as Poland (Sztompka, 1996; CBOS, 2020). Activities of local authorities related to energy transition tend to be ineffective, even though they enjoy higher public trust than those of central government (Sześciło, 2019; CBOS, 2020). This state of affairs results from the following:

a. The low level of social trust in the public sector and in institutionally promoted technological innovation;

b. The low, though increasing, social awareness of the correlation between issues of environmental quality ( $\mathrm{smog}$ ) and energy efficiency;

c. The skepticism on the part of voters who prioritize the issues of thermal modernization farther down the list of current needs;

d. An outdated perception of the issues associated with municipal energy supply;

e. The municipal authorities' limited resources and competence to negotiate with external entities regarding the coordination of the energy transformation processes constituting an integral part of revitalization.

The issue of heat supply modernization became the subject of intense public debate in Poland after 2015, mainly owing to the social initiative of the Polish Smog Alert [Polski Alert Smogowy]. ${ }^{4}$ The publication of daily data on the level of air pollution ${ }^{5}$ authenticated the need to define and supplement the regional and municipal environmental and climate policies with special documents called anti-smog resolutions. ${ }^{6}$ Under pressure of social expectations, a number of programs had been launched, which developed the legal and financial framework, mainly for replacement of coal-fired boilers and thus accelerated implementation of the provisions of Directive 2008/50/EC of the European Parliament and of the Council of 21 May 2008 on ambient air quality and cleaner air for Europe (CAFE). ${ }^{7}$ Currently, the "Clean Air" initiative is one such program, which more than $80 \%$ of Polish municipalities have signed up for. It distributes subsidies for thermomodernization of houses and replacement of old heat sources with more ecological solutions (Portal Komunalny, 2021). Eight commercial and cooperative banks have recently joined the National Fund for Environmental Protection and Water Management [Narodowy Fundusz Ochrony Środowiska i Gospodarki Wodnej], in order to support the financial servicing of not only the "Clean Air" program itself, but also the entire anti-smog initiative (NFOŚiGW, 2021).

In the last five years, an increase in the energy standards offered by multi-family commercial housing has been observed (new condos). Similar changes have been taking place in middle-class single-family housing. The market demand for technologies and products offering alternative, more efficient heat supply solutions has been triggered. Both types of activity are, however, addressed to the 
investor communities having the resources and competences necessary to apply for the aid funds. This sets barriers to the dissemination of the modernization process, which has been limited by the low level of public funding and the administrative approach to the cooperation with the local community that is too narrow and strictly understood as the private sector. This results in the preference for random partial investments, which do not fully correspond to the scale of the needs nor to the necessary complexity, both in terms of thermal modernization itself as well as the broadly understood revitalization (urban regeneration).

Analysis of the municipal development policies implemented in the Pomeranian Voivodeship after 2015 substantiates the list of the nationwide shortcoming impeding the undertaking of comprehensive activity, in the context of urban structure revitalization and the historical rural assumptions (JadachSepioło et al., 2018). According to Polish law, revitalization is

A process of recovering degraded areas from the state of crisis, implemented in a comprehensive manner, through integrated activities for the local community, space and economy, concentrated territorially, carried out by the revitalization stakeholders on the basis of the municipal revitalization program. ${ }^{9}$

The central authorities' insufficient support for the local activities is manifested by the lack of effective legal and financial instruments, including the public-private partnerships (PPP) formats that are necessary when it comes to the energy issues constituting the domain of commercial activity (Tang et al., 2010). This results in fear, on the part of municipalities, of initiating long-term urban processes that require durable involvement of significant financial resources and advanced-level execution of integrated planning and implementation. This results in defective elimination of the difficult aspects from the scope of revitalization. Some of these aspects, such as energy and heat, are moved to the further stages of implementation or qualified as part of the private sector domain (Wis-Bielewicz et al., 2018). Under the veil of revitalization, the delays in the implementation of the national social policy (social revitalization), which in the previous stage had been pushed aside by the classic renovation activities, are now compensated for by abandoning a more comprehensive approach (Przywojska, 2016). Moreover, the concept of energy poverty has been now introduced into the Polish public debate. The 2017 diagnoses carried out by the independent Institute for Structural Research [Instytutu Badań Strukturalnych] indicated that multidimensional energy poverty affects approximately 1.3 million out of the 13.57 million Polish households (9.8\%), which is equivalent to 3.35 million out of the 38 million people living in Poland (Sokołowski et al., 2021). These data show that the existing methods of supporting thermal modernization, mainly through financial subsidy programs dedicated to individual middle-class investors and municipalities, bypass one of the key problems in the country.

The fact that the issue is understood in sectoral terms has transformed the public debate on revitalization, which has been dangerously reduced to the 
technical and renovation dimension. This mainly stems from the possibility of obtaining EU funds. It should be remembered that in the leading EU countries, the fundamental processes of urban regeneration are already being addressed, while the issues of energy and technological change have become the core of current urban policy and are implemented with the awareness of the importance of a comprehensive approach and the ability to achieve synergistic goals. In Poland, where habits of revitalization have not been developed; this provides another incentive to detach this issue from the core of revitalization policies and formulation of a defective concept of energy revitalization, dealing with only technical thermal modernization. In view of the enormous needs, this logic focuses the public sector initiatives on energy-efficient improvement of its own (municipal) resources, as opposed to being oriented at development of systemic municipal programs that would steer the process of the private sector actors' broad involvement in the transformation. Such exceptional cases as the national leader in revitalization - the City of Sopot (ESCO, 2017) or the developing Geotermia Podhalańska S.A. (Bujakowski, 2010; Pająk et al., 2020) - validate this thesis by illustrating the possible scale of acceleration not only through implementation of projects, in a public-private partnership format, but also through the use of the scientific community's potential to act as the catalyst for the change.

Insufficient dissemination, among the municipal authorities and local communities, of knowledge on the methods and solutions used in the national initiatives characterized by the parameters of complex pilot projects has been another problem affecting the implementation of integrated spatial policy and the energy change (Jadach-Sepioło et al., 2018). The experience of urban labs, (e.g., the urbanlab.gdynia.pl active since 2019) that are dedicated to revitalization process, constitutes a special category, still poorly scientifically documented. The dissemination of the know-how and the constant support by academic entities are often the reasons behind the innovative activities on the part of local communities and private business (Martyniuk-Pęczek and Rembarz, 2016). This long-term activity, the foundation of which is social trust, places the multi-faceted renewal of the local community and the environment at the center of its mission. Creative organizational schemes as well as transfer of the know-how take place under the assumption that the local community is an equal, active partner and the main beneficiary of the changes (the subject in the process). In this context, it is necessary to develop new, alternative organizational models that would facilitate the implementation of systemic solutions as a commonly available good. Only this may cause a change in the social attitudes and, consequently, reform the central policy, moving it towards stabilization and activation of support for energy transition.

\section{Energy transition under Polish settings}

The complexity of actual conditions, both political and technical, in reality results in the process of energy transformation in Poland remaining in the early 
phase. The most important issues that should be taken into account here are the following:

a) The fundamental disparity in the characteristic of urban structure with its strong spatial outline of the post-socialist development phase: the dominance of large-scale multi-family housing cooperatives (industrialized technologies, district heating, modernist form) as against the single-family housing dynamically emerging in the liberal processes of suburbanization after 1990 and the historical buildings from before 1945 (largely rebuilt), which was covered by the policy of structural revitalization as late as 2015;

b) The weak position of the public sector in the process of shaping the city and its infrastructure (neoliberal socio-economic development paradigm), combined with a lack of experience in public-private-partnership implementation and weak status of participatory planning in the decision-making processes (the urban activism emergent first after 2010). The incoherent Polish model of urban planning, constantly experiencing changes to its legal framework, addressing a series of ad hoc issues, has resulted in a failure to implement forward-looking modern development strategies that are based on the results of in-depth analysis and modern knowledge;

c) Privatization of municipal technical infrastructure and of council and cooperative housing (modernistic large-scale housing districts of the 1970s), taken over after 1990, have introduced market principles to the broadly understood urban energy sector. This process has deepened the state of low integration of municipal planning and the possible range of public investment into infrastructure systems, that are of key importance for the current phase of energy transformation. In the situation of constant shortages in local public finances, the initiatives undertaken by local authorities are dependent on the possibility of obtaining external funds, mainly via EU programs. The ongoing differences in the range of modernization needs, which characterizes urban structures in the leading EU countries as compared with Poland, leads to difficulties in making the most effective use of the available EU funds;

d) The use of scientific research results in Polish city planning is not a common practice. Strong limitations to this cooperation are mainly the pace of the spatial changes and the legal regulations concerning public finances. The practical experience of the last three decades also reduces openness of the public administration bodies towards the implementation of projects requiring innovation burdened with unknown technical and political risk (Rembarz, 2018a). The practice of applying public funds for implementation of model or pilot projects, not only universal ones, but also those adapted to regional or even local conditions, is not common. Rare examples of such a practice devoted to the issue of urban renewal are mainly initiated by researchers performing grass-root activities, e.g., replacement of coal-fueled boilers with biomass-fueled cogeneration units in Żychlin (Cenian et al., 2015a, 2015b), innovative poultry feeder gasification in Olsztyn (Dudyński 
et al., 2012), modernization of the district heating system in Łomża (Cenian et al., 2019), implementation of geothermal heating systems by Geotermia Podhalańska (Bujakowski, 2010; Pająk et al., 2020) or waste heat utilization (Duda and Cenian, 2013).

The small number of such developments also results from the existing model of science financing in Poland, which does not support fruitful cooperation in the field of research implementation for local authorities (Orłowski, 2013). The experience of EU countries shows that innovations (technological changes) are stimulated by public funds, due to the high risk, which the small-scale private sector is not able to bear. The public sector in the EU countries is therefore committed to the development and testing of new technologies as part of pilot projects, which are essential if model solutions are to be designed. The road to successful innovation leads through the technical and commercialization-related difficulties, the so-called "death valley." Owing to the public patronage and promotion, credibility and market critical mass are achieved, which activates private business and the large-scale implementations providing these entities with the necessary profit and risk minimization. Due to low public support, the innovation pilotage carried out by the Polish private sector must bring measurable profit right away. An attempt is therefore made to jump from the idea to actual implementation, reducing the time and costs, which theoretically is supposed to be more beneficial. In practice, however, it often leads to bankruptcies and a growing distrust in national innovations and the cooperation with science in general as well as confirming the assumption that it is better to purchase proven foreign technologies. Ultimately, domestic innovation is relatively weak and focused on the problems of adapting foreign solutions to local conditions, which is not tailored to the local needs and conditions. These circumstances affect the local authorities' attitude towards innovation, who, by wanting to bypass the period of pilotage and implementation research, bear too much risk and suffer the consequences of setbacks or, by not wanting to take the risk, become the main obstacle in the implementation of local innovations. That is why it is so important to change the public sector's modus operandi to one which would allow for wider participation of local communities, and of local business in particular, in the creation of a climate for technological and social changes. ${ }^{10}$

For this reason, innovation in the field of research implementation must include efforts toward formation of new partnership models. These tools now accelerate creation of platforms, helping institutional entities to come together and enable implementation of new large-scale technical solutions in an urban environment. The issue of setting functional public-public partnerships between traditionally non-cooperating entities from the public administration sector constitutes a core task. This can be a real catalyst for realization of the EU energytransition agenda that requires a complex interdisciplinary approach.

The issue of energy transition in rural areas constitutes a specific topic. The conditions that exist there illustrate the fundamental neglect by the State over several decades. The socialistic regime placed focus on industrialization. After 
the "Solidarity Revolution," the focus has again been placed on urban metropolitan areas (due to the EU agenda). The lack of public support resulted in wider openness towards potential public-private partnerships, which are supported and encouraged by local communities.

This is beneficial for implementation of projects, requiring close cooperation of the public administration and strong support of the social side. Projects presenting a coherent and clearer vision corresponding to the scale of rural areas are favored, which suit the perspective of the political agenda and the community social perception. In peripheral communes (even those operating in the shadow of metropolitan urban-core cities), individual initiatives - of economic entities, social activists or innovative business - are becoming more visible. This can trigger processes of more extensive change; first, of social awareness, second, of space, also in its economic and cultural dimension of metropolitan cities.

The role of EU programs in the support for energy transition in Poland should not be ignored. On the one hand, they pertain to the development of research and dissemination of knowledge among local governments, and on the other, they allow for the execution of implementation programs. The funds allocated to the implementation are of particular importance here, as they constitute a significant incentive for local governments and local heating companies, not only to modernize the existing networks or optimize the energy consumption in private buildings, but also to expand these networks and introduce new products and services, using renewable energy or heat recovery. The EU financial programs, covering up to $80 \%$ or more of the investment costs, constitute the main incentive for undertaking innovative activities (Dworakowska, 2018). The condition of an established partnership and the requirements regarding the scope of socialization, underlying acquisition of these funds, constitute an important factor softening the neoliberal business attitude of both the public and the private sector. In Poland, the apparently obvious and simple synergistic activity at the public-private crossways has been slamming into the imperfect public procurement law and the inflexible, in terms of the investment specificity in revitalization zones, legal framework defining financing and organization of cooperation. The amount of the formalities associated with micro-scale activities, just as in the case of much more complex and significant projects, has been largely discouraging officials from undertaking any initiatives that would support the residents' property modernization activity. In spite of these problems series of Baltic Sea Region (BSR) and South Baltic Programs (SBP) projects contributed significantly to energy transition issues in cities and rural areas in Pomerania Region, e.g., LowTEMP: Low Temperature District Heating for the Baltic Sea Region, Act Now: Action for Energy Efficiency in Baltic Cities and BP: Bioenergy Promotion (Krug et al., 2015; Cenian et al., 2019; Pakere et al., 2018; Feofilovs et al., 2019; Konkol et al., 2020).

\section{Revitalization: Living Lab (R_LL)}

In the field of urban renewal, the energy aspects are most commonly associated with the concept of the Smart City, which can be equally legitimately 
implemented both in modern and historical urban districts, as well as in rural settings (Bevilacqua and Pizzimenti, 2016). As shown by the experience of the more technologically advanced European countries, a permanent and effective energy transition is achieved when it facilitates the choice of a pro-ecological lifestyle for individuals and communities. This requires innovation in both the technical-organizational and psychological-cultural dimensions.

The concept of a Revitalization: Living Lab as a research method is a kind of hybrid approach. It uses typical urban planning tools, such as design or planning lab (United Nations Human Settlements Programme, 2016), used mainly in the promotion of participatory planning, in conjunction with the Living Lab method derived from technical sciences, mainly Information Technology (IT). ${ }^{11}$ ENoLL - the European Network of Living Labs, ${ }^{12}$ specifies that

A Living Lab is an open innovation environment in real-life settings in which user-driven innovation is the cocreation process for new services, products and societal infrastructures. Living Labs (LL) encompass societal and technological dimensions simultaneously in a business-citizens government-academia partnership.

Current application of the Living Lab in Smart City research defines this concept in two different ways. Firstly, as a derivative of urban infrastructure, i.e., an early technological version (the so-called beta version) requiring testing, verification and technical modification arising from user experience. Secondly, as a socio-infrastructural environment, i.e., a democratic social concept in which the bottom-up processes resulting from local needs and expectations shape the technical solutions. In this concept, the LL model is used in three different forms (Bergvall-Kåreborn and Ståhlbröst, 2009):

(1) As a permanent activity fully adapted to the local context of the place, with limited possibilities of repeating the solutions obtained under different conditions;

(2) As a form of temporary activity, dependent on the changing of the project phases, technology and financing cycles, exposed to the loss of the features of the creative connection with the place (place-making) and the transformation into a temporary event with solutions replicable in other settings;

(3) As a multi-stakeholder platform where the role of local partners (residents, activists) is to balance the top-down solutions that are purely technical, initiated by influential commercial forces.

There is a tendency to ambitiously perceive the potential of LL to transform (in the third approach) into a kind of participatory management model, enabling the local community to exercise political and expert supervision over technical infrastructure (Cardullo et al., 2018). This approach is particularly dedicated to the urban structures representing traditional spatial parameters and corresponding 
social context, i.e., revitalization areas, also those with a typically rural profile (Rembarz, 2018b).

The possibility of using the LL format for research on revitalization is clearly proven by the APRILab project team: Action Oriented Research on Planning, Regulation and Investment Dilemmas in a Living Lab Experience ${ }^{13}$ "the living lab means any kind of user-centered research and development in an open-innovation ecosystem, that has a territorial context (e.g., city, agglomeration, region) and that integrates concurrent research and innovation processes within a public-private people partnership" (Wallin, 2014, p. 6). Three main issues illustrate the genesis and application of the Living Lab format in current research: (1) a research environment for technological solutions, (2) a distributor and active base of knowledge and tools and (3) a platform for self-organization of groups and communities. While developing the Guidelines to Define and Establish an Urban Living Lab, the APRILab team has indicated that the concept of Living Lab in urban studies is strongly conditioned by the context of the problem field and may modify its definition depending on the research profile (Wallin, 2014).

The introduction of the high technology dimension, derived from the Smart City scope, to everyday practice of urban planning, has been carried out in Poland under a neoliberal planning paradigm, which assigns to the public sector a weak partner role. Polish local authorities rarely undertake the initiative towards establishing new or alternative development strategies addressed to privately owned land. The enormity of the challenges associated with the constantly intense crosscountry development dynamics means that local councils are not pre-prepared to deal constructively with the subject of technological, and thus social, changes. A strong threat has been observed connected to the issue of new technology implementation, not conditioned by any special urban policy and modern legal framework. Weak expertise means that local communities confuse the notion of "Smart City development strategy" with plain "public consumption" of the commercial offer on technological products (Rembarz, 2018d). In this context, both the very idea of Smart City and the implementation of research Living Labs may too often lead to their use only as technical and modernization tools on the basis of a simple commercial calculation. Without proper respect given to the local public participatory involvement, it may enforce a neoliberal format of management and planning, deepening the social divisions and expanding the sphere of exclusion, that is, limiting civil liberties and destroying local democracy (Cardullo et al., 2018).

The R_LL method applied here has been adapted to the current local conditions and needs of the Pomerania Region. It was not possible to implement a long-term functioning R_LL of a similar profile, as a pilot project, programmed with the indication of strict goals in the envisaged time perspective. This is a countrywide universal problem in Poland. Both of the cases described below of R_LL Lubań and R_LL Orunia are examples of a process initiated by bottom-up impulses coming from outside the public sector. The first one was started by an individual fascinated with both the historical site and the usage of renewable energies. The second has come from a group of local activists (founders of GFIS 
Gdańsk Foundation for Social Innovation ${ }^{14}$ ), who have become engaged in the social development of Orunia, a deprived district of Gdańsk.

Both R_LLs are also examples of a new way of implementing interdisciplinary research on Polish cities. In this alternative approach the external partner for the two-way feedback transfer of knowledge is not a public institution, but the local activists: the voluntary council advisory board (sc. district council), informal representatives of the local community, locally acting NGOs or the local entrepreneur(s). The beginning of cooperation, through non-binding scientific advice, led to the development of undertakings that could translate into further model pilot projects. Both examples have become a unique environment conducive to the generation of complex innovation, making clearer in the R_LL structure the importance of the large-scale spatial dimension: territory and community (metropolis, city, village). The possibility of participation and, at the same time, initiating and observing the subsequent stages of the transformation process of Luban and Orunia, allows both cases to be included in the R_LL formula. In turn it allows the scientific processing of the results recorded there. Adoption of such an understanding of the R_LL format corresponds to the main parameters of the revitalization concept. R_LL operates as a multi-faceted, long-term process of change, restoring the original vitality to the degraded historical structures - the ability for independent socio-economic functioning with appropriate protection of historic values. Adoption of this method results from three premises:

1. A series of activities, aiming at the know-how transfer to the practice, undertaken by the researchers in Poland (in the disciplines of urban studies and engineering), encounters a lack of interest on the part of the local councils and the municipal administration, who are distrustful of urban innovation that is open to public involvement. Direct cooperation within community planning formats towards developing the "bottom-up initiative" creates a favorable environment for bringing changes into practice and assuring increased political support from the local authorities for such projects;

2. An organized public involvement in research addressed to urban development, especially the implementation of innovative technical solutions, is a new approach in Poland. It is all the more valuable as investments assuming interdisciplinarity in the field of innovative urban engineering are still rare in the country. In the revitalization process which requires synergistic effects, energy transformation means not only technical modernization introducing the latest solutions, but far more innovation in management accelerating positive social change;

3. Energy transition, under Polish conditions, is only possible when citizens, especially the young generation, support it and exert pressure on the local and national administration. Their participation in the regional and national programs devoted to prosumer ideas, such as "Mój prąd" (My electricity) or "Czyste Powietrze" (Clean air) is crucial. The first program has already enjoyed great success: around 508,000 new prosumers connecting to grid (till March 2021) 3,293.8 MWe in PV installations (Czechowicz, 2021). 


\section{Between slow and smart: R_LL localization in the Gdańsk-Gdynia-Sopot metropolitan area (OMGGS)}

The Pomeranian region is polarized concerning population density. The urban core developed around the metropolitan area of three cities Gdańsk-GdyniaSopot. The so-called Tri-city with its functional urban area forms a one and a half-million-strong metropolis with a vibrant cultural and economic center (see Figure 8.1). The metropolization process generates dynamic local migration (Sejmik Województwa Pomorskiego, 2021), resulting in a depopulation of the remaining rural and semi-rural sub regions of Pomerania. The expansion of the urbanizations in limits of OMGGS $\left(11,610 \mathrm{~km}^{2}\right)$ does not mean its high quality. Urban peripheries with their "net-city" structure are causing enormous problems in terms of infrastructural systems. New urbanizations perform as a cluster of individual ventures, fulfilling minimal standards of planning requirements. Local interpretation of spatial plans avoiding rational, modern and coherent vision, works against an increase in energy efficiency. It is therefore urgent to present alternative development scenarios. Unilateral promotion of the Smart City image in the very center of the metropolis, brings too much expectation

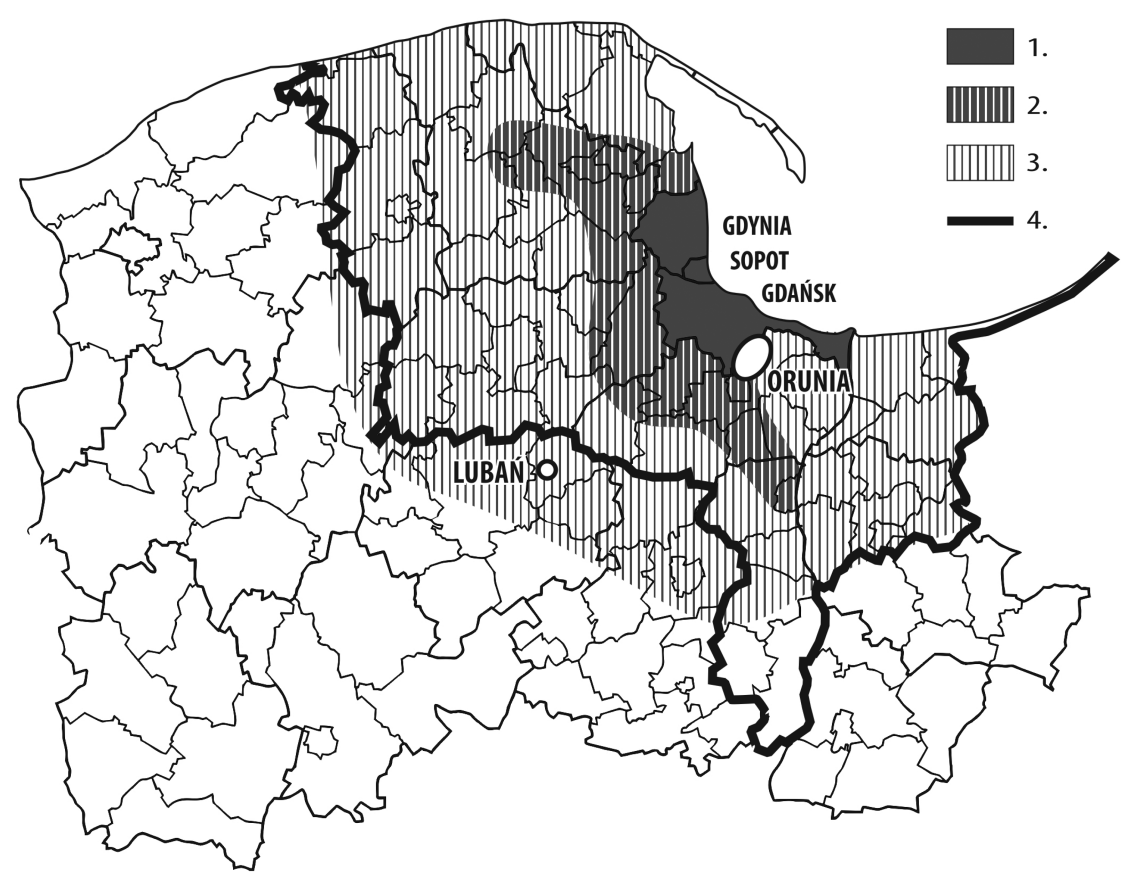

Figure 8.1 R_LLs Lubań and Orunia in the Pomeranina Region (source: the authors, graphics B. Labuhn). Key: 1. metro core area sc. Tricity agglomaeration GdańskSopot-Gdynia, 2. functional urban area: range of suburbanization (developed after 1990), 3. functional urban area: exurban rural and semi-rural peripheries, 4. Metropolis Gdańsk-Sopot-Gdynia OMGSG - union of municipalities. 
towards slow-life environments, suiting alternative vision of the development in the ex-urbs (Rembarz, 2019b). The process of quality increase of urban sprawling is the response to the acceptance of the fact, that the netcity is the current model for development of a contemporary metropolis (Rembarz, 2019a). The issue of energy management has potential to stimulate the imagination of actors participating in the creation of the contemporary sub- and exurban areas. The use of the historical developments inselbergs in the rural landscape, to visualize the existing transformation possibilities, teaches how to obtain synergistic effects (Rembarz, 2018c). It is not a routine practice for peripheral local authorities in Poland, neither in the private nor the public sector. Such an approach, however, currently is the key goal of a comprehensive revitalization policy. It is also an obvious assumption of the entirety, of the current urban-planning paradigm in Europe, which is only just breaking through the practices of the Polish administrative system, that have been shaped under rapid transformational conditions.

\section{The Lubań Revitalization: Living Lab I}

The Lubań R_LL I is located in the Kashubian village of Lubań (kasz. Lëbòniô) the history of which dates back to the Middle Ages (first mentioned in 1280). The population of the rural community in 2019 was about 2,000 inhabitants (Urząd Gminy Nowa Karczma, 2020). Till the end of World War II, the village was a manor grange with a XIX century mansion and an extension housing a distillery, surrounded by a historical park. The complex, holding the status of a state-owned farm during the communistic regime, was a renowned regional agricultural innovation center ensuring work and basic services like grammar and agricultural schools for over 3,000 people, along with the village church and shop options. Already at the beginning of the 1990s, the village was equipped with an independent sewerage system and a district heating grid supplying heat and domestic hot water to the housing quarters, the grange, the mansion and the Pomeranian Agricultural Advisory Center (PODR), adopting the former agricultural school buildings. The system was powered by a culm-fueled boiler house located in the old distillery. Later, two $900 \mathrm{~kW}$ coal boilers were located in an adjacent building. The historical heritage of this place had been significantly damaged, which was the common fate for most manor estates nationalized after 1945. After the system changes of 1989 , over many years, Lubań was an example of the slow degradation and depopulation of rural areas, hopelessly waiting for a public development strategy (see Figure 8.2).

In 2012, the Institute of Fluid-Flow Machinery Polish Academy of Sciences (IMP PAN) supported by the Energy Department at the Marshal Office in Gdańsk, initiated cooperation with the PODR, for development and promotion of new technologies in the field of distributed energetics for rural areas. The PODR Center, the largest employer in the region, actively supports both agricultural innovation and the energy prosumer ideas in rural areas. Nowadays, Lubań is known mainly for the Kashubian Agricultural Autumn Fair (attracting up to 50,000 visitors), a platform to promote ecoenergies and Lubań as a model of ecoenergy solutions. In 2015 in 


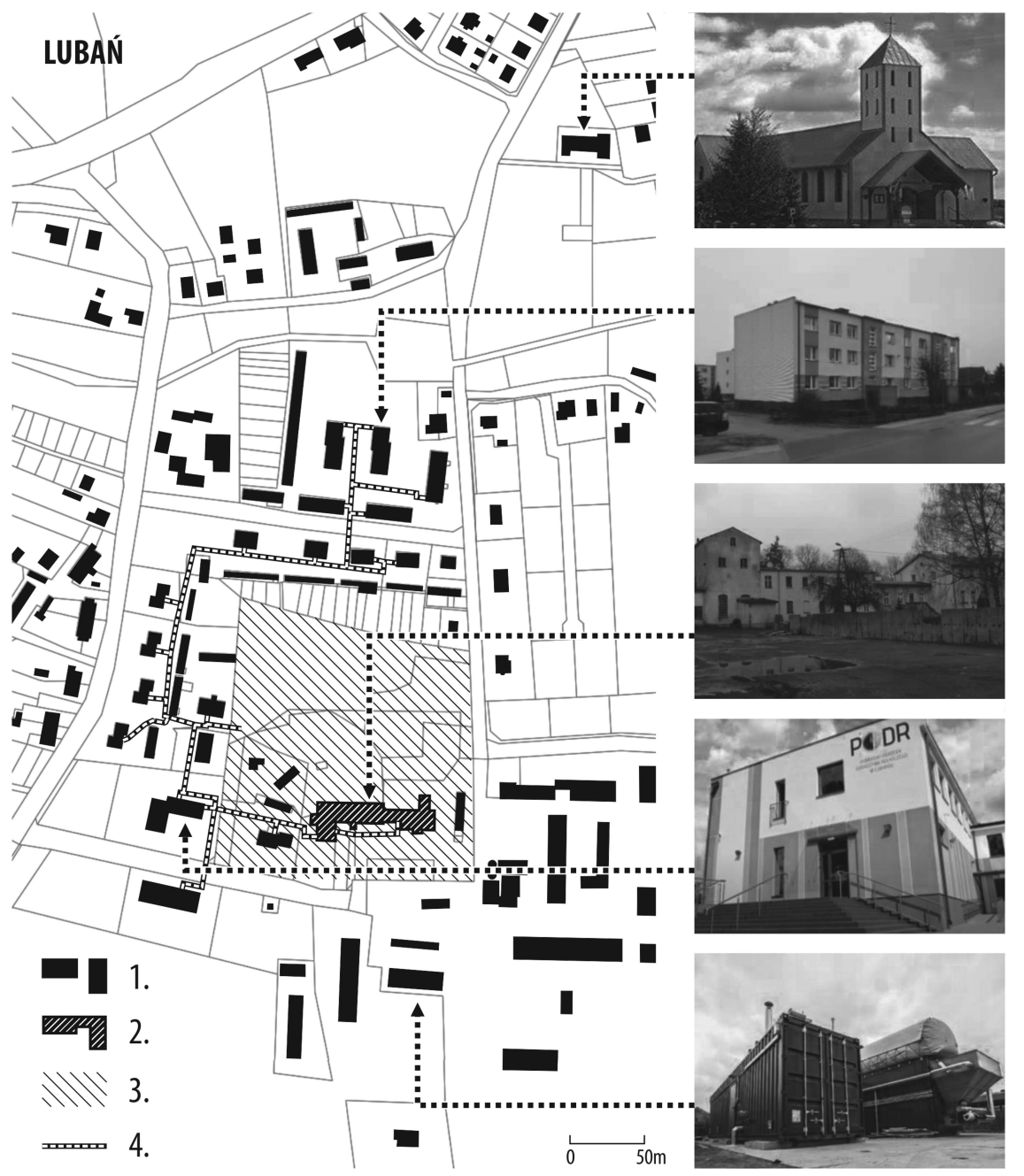

Figure 8.2 Lubań the R_LL I. On the left: map of Luban housing structure; on the top right: photos of (A) the village church, (B) the former PODR workers housing estate from 1960s, Lubanianka Housing Cooperative (LHC), after the thermomodernization in 2016, (C) the mansion with the distillery, (D) the former agriculture school building in Lubań, renovated and turned into the new PODR headquarters, (E) the biogas microinstallation (source: the authors, graphics B. Labuhn).

active cooperation between the IMP PAN, the Gdańsk University of Technology (GUT) and the private Eco-Construction company, the first microbiogas plant was built as a new educational infrastructure on the PODR plot. This pilot installation of the project "Integrated Technologies for Fuel and Energy Production from Biomass, Agricultural Waste, etc." in the Strategic program - Advanced Energy Technologies 
of the Polish National Centre for Research and Development (NCBR) was used as a Living Lab for subsequent investigations and biogas promotion by scientific institutions and the PODR till 2020. Gradual improvements have led to changes in both technical and socio-economical domains.

During the interaction and discussions with the local community and the main public-sector stakeholders (especially PODR), the first author of this chapter, as the $\mathrm{CEO}$ of Eco-Construction Ltd., recognized the significance and the high potential of this historical yet degraded village. Its revitalization can be an exemplary subject of energy transition in rural areas. As early as 2015, the company therefore designed (in cooperation with IMP PAN) a new, energy plus PODR headquarters (Lubań) (see Figure 8.3.D), while the PODR decided to move its headquarters from Gdańsk. The design included a $40 \mathrm{~kW}$ solar installation on a field (executed on and connected to the grid), a solar parking area (still a concept), a $40 \mathrm{~kW}$ wind turbine and $140 \mathrm{~kW}$ ground source heat pumps (already executed, supplying two PODR office buildings). In July 2017, a new (totally refurbished) PODR Centre was opened.

In the meantime, a series of interactions and discussions with local citizens and activists led to the development of plans for revitalization of the entire village, including the mansion with the distillery as well as an energy supply system. In 2016, as the first step, Eco-Construction Ltd. initiated the Revitalization: Living Lab I activities aimed at energy transition towards an energy plus village, which involved development of plans in cooperation with the residents and the local administration as well as IMP PAN participation. The revitalization plan included a solar parking (see Figure 8.3.A), the renovated mansion house with an historical park and the educational path (see Figure 8.3.B), a new private housing estate (see Figure 8.3.C), a new $250 \mathrm{~kW}$ biogas plant exploiting the biowaste available locally (i.e., pig, cattle and poultry manure, grass and municipal biowaste, etc.) (see Figure 8.3.D), a $40 \mathrm{~kW}$ photovoltaic microinstallation and a windmill (see Figure 8.3.E), the Education and R\&D Centre (see Figure 8.3.F) and an innovative, low temperature, fourth generation district heating system with a boiler house (located in the old distillery, in the left wing of the mansion). Meanwhile, as a part of the preparation, Eco-Construction Ltd. bought and invested in an old dilapidated distillery, where the new innovative heating system is being designed, including a biogas/pellet fueled boiler, supported with a PV installation, solar panels and air source heat pump; it should replace the oversized $900 \mathrm{kWt}$ boilers fueled by highly polluting culm (coal waste).

The Revitalization: Living Lab I activities included a series of meetings related to:

(1) The design plan for an energy cluster - developed by Eco-Construction Ltd. in cooperation with the IMP PAN and the GUT (especially LINTE 2) ${ }^{15}$;

(2) Presentation of the design plan during several meetings with local citizens and activists, the municipality and the PODR administration, as well as members of the Polish Parliament;

(3) Development of the Low Temperature District Heating (LTDH) idea with participation of Lubań citizens and the Lubanianka housing cooperative; 

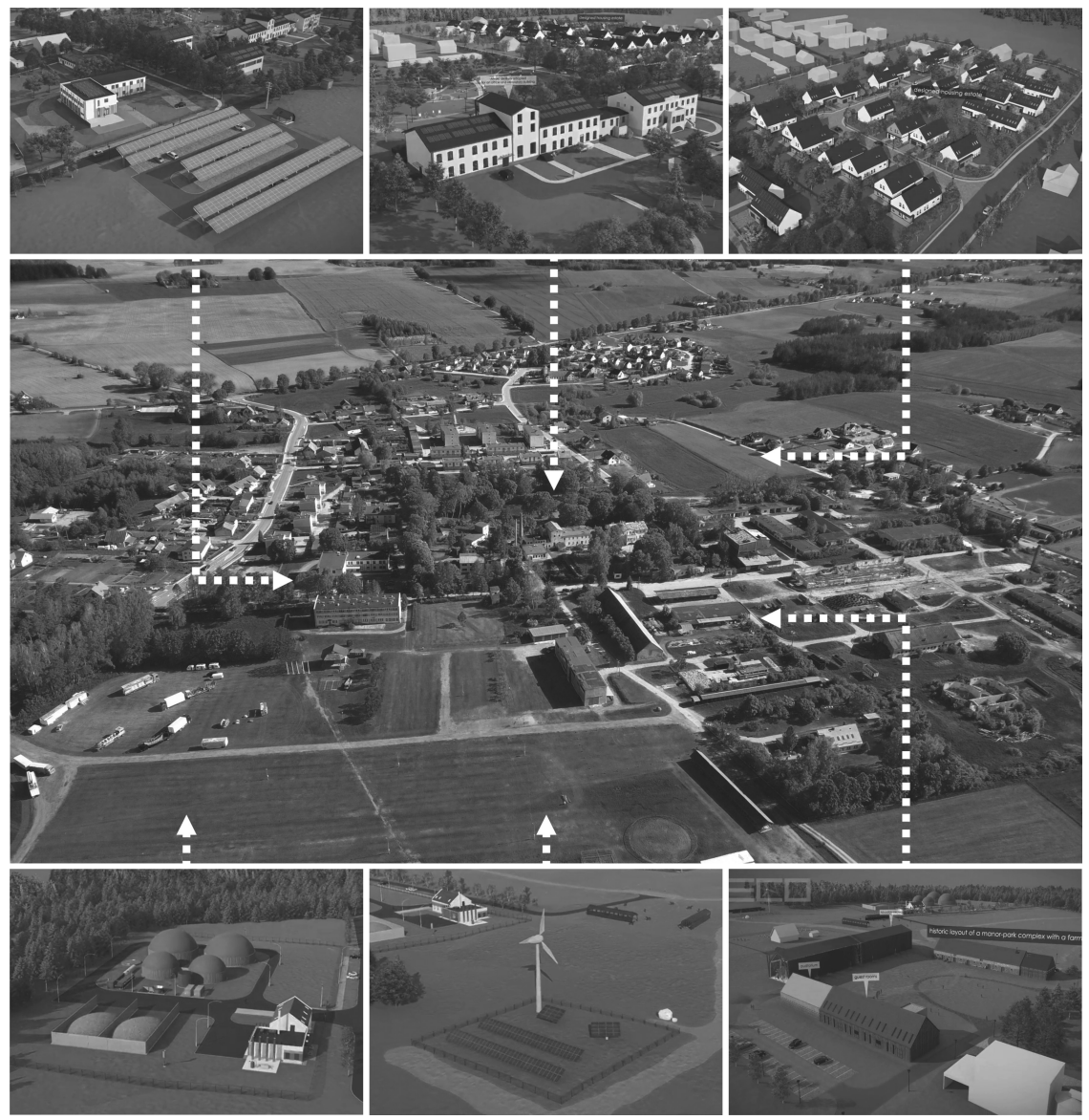

Figure 8.3 Aerial photo 2019 of Luban and the village revitalization concept, with the Pomeranian Energy Cluster infrastructure designed by Eco-Construction Ltd. (Source: Eco-Construction Ltd). From the top left: (A) solar parking in front of PODR headquarters, (B) renovated mansion house with historical park and the educational path (revitalization finished in 2020), (C) private housing estate. From the lower left: (D) biogas installation, the wind mill turbine, (E) a $40 \mathrm{~kW}$ photovoltaic microinstallation and a windmill, (F) the Education and R\&D Centre.

(4) The signing of a Letter of Intent (LoI) with the local cooperative, in order to refurbish an existing common heating system;

(5) Presentation of a design plan during various project meetings with companies, regional and national authorities, and lobbying with the decision makers;

(6) Development of an Educational Path as part of the Living Lab on RES and waste management. 
These activities led to the signing of an LoI related to the Pomeranian Energy Cluster (located in Lubań), between Eco-Construction Ltd., local authorities, the Linte2 (GUT) and the IMP PAN (2016). In 2017, Eco-Construction Ltd. presented the first draft of the revitalization plan for Lubań, developed in cooperation with IMP PAN and local activists, with emphasis on RES (see Figure 8.3). Wide promotion of the Revitalization: Living Lab I and the designed plan began.

Meanwhile, Eco-Construction Ltd., upon the request of the PODR, also designed the revitalization plan, including thermomodernization of other, older PODR buildings, with implementation of a ground source heat pump (140 kW) and $10 \mathrm{kWp}$ PV modules on the roof. At the same time, the company developed, along with another investor, a concept for a new eco-profiled kindergarten. The building permits are ongoing.

In 2019, the designed micro PV farm $(40 \mathrm{kWp})$ was built by the PODR. Simultaneously, the activities aiming at replacement of the old, oversized coal boiler house supplying the heating to the Lubanianka Housing Cooperative (LHC) began. It is well-known - see, e.g., (Cenian et al., 2019) that after the thermomodernization, the heat demand for houses should drop drastically and the heating systems should work more efficiently when it is matched to the heat demand. However, the existing boiler house is equipped with two large $900 \mathrm{~kW}$ coal boilers, although the average heat demand is a maximum of $350 \mathrm{~kW}$ in winter and drops to $60 \mathrm{~kW}$ during summer. It has been estimated that the yearly average efficiency of the system approaches $50 \%$ and drops to $20 \%$ during summer, when only domestic hot water is in demand.

The assessment results were presented to the LHC administration and during a housing cooperative gathering. After a series of meetings and clarifications, an LoI was signed in May 2020 between the LHC, Eco-Construction Ltd. and IMP PAN which has opened the road towards the LTDH system implementation in Lubań. A new online monitoring system of heat demand and supply is being designed, which will enable better assessment of the existing grid and boiler house. The design for a new location for an appropriate pellet/gas boiler has been developed and sent for a building permit. It takes into account the possibility of heat supply for new housing estates, hotels and restaurants in an Education and R\&D Centre (see Figure 8.3), implementation of various RES, including heat-storage systems enabling appropriate heat-demand response. This would be one of the first LTDH systems in a Polish rural area and a showcase benchmark for similar systems.

The municipality of Nowa Karczma (which includes the village of Lubań) strongly supports the concept of the Luban revitalization. In the years 20182019, the municipality designed and implemented a new street plan in Lubań, taking into account the revitalization plans. Additionally, in 2020 as part of the Wasteman project of the South Baltic Program, ${ }^{16}$ the municipality implemented an educational path, as part of the R_LL I, in relation to waste management and RES. 


\section{The Orunia Revitalization: Living Lab II}

R_LL I in Lubań represents results and experience, which is of importance for the further development of the R_LL II defined for the semi-rural suburb in Gdańsk - Orunia, populated by ca. 14,000 inhabitants (Rembarz, 2018c). Ultimately this initiative could transfer into the model of the unique agrihood, such as the Energy Improvement District located in the zone threatened by the effects of the sea level rise (Fischer et al., 2020).

Located $3 \mathrm{~km}$ south of downtown Gdańsk, Orunia has been serving as a town-village gate since the Middle Ages. The existing orchards and farms continue their activities dating back to the mid-16th century, when Dutch Mennonites, engineers and settlers, came to be involved in draining the Vistula Delta swamps. The post-war population exchange as well as the decades of underinvestment and neglect, has resulted in today's Orunia/Św. Wojciech districts, characterized by complex social problems, leaving an imprint on the image of this semi-rural, green, idyllic suburb. Despite this profile, one can find in Orunia all types of urban tissue-samples from the over 200-year-old farmhouses in Dutch-like style to the modernistic large-scale modular housing of the 1970s.

The R_LL II zone was chosen due to its unique profile representing all types of urban structure that is characteristic for rural suburbs and villages as well as for small and medium sized towns. With its location at the urban edge and prominent location at the main entry road to Gdańsk City Center, Orunia represents all the best possible features to become an experimental laboratory and a display area of revitalization characterized by a strong energy transformation profile. Despite these features, it is not an elite district. Orunia always has accommodated newcomers, but since the 1970s it has become a district of a lower social status (see Figure 8.4). The structure of land ownership is dominated here by communal properties of the City of Gdańsk, which until 2016, has minimized any obstacles to the implementation of publicly supported investments.

The decision to define the whole process of ongoing change in recent decades in Gdańsk-Orunia as a R_LL, arose out of the studies on modern research methodology. Direct transfer of the R_LL formats designed for American or German conditions meets inevitable obstacles. The foreign experience in implementation of similar actions i.e., introduction of technical and organizational advancements to improve the quality of life in degraded urban environments, illustrates the difference in scale and program assumptions. In the specific Polish context, the most difficult to overcome is the weak and underfinanced position of the public planning and revitalization incentives. That in turn influences the character of the research, limited by the profile of the public partner.

The Orunia R_LL II was initiated owing to the informal cooperation between the GUT (Gdańsk University of Technology) and the GFIS Foundation, operating locally in Orunia. The foundation acts as a facilitator of the local community. Starting from 2010 in the "Hospitable Haven" community house run by GFIS and leading debates on the vision of the district development in the series "I 
Revitalization: Living Lab 173

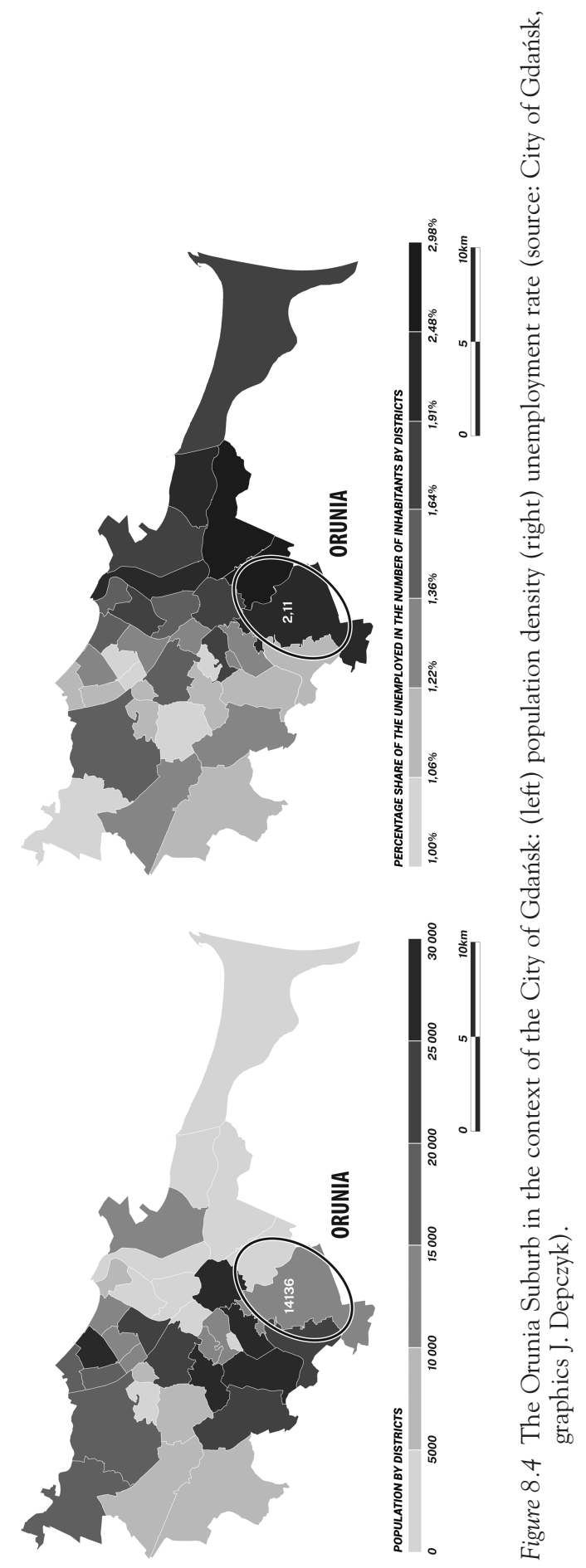


see Orunia as Great." The series touched on problems of energy costs, which threatens the disadvantaged groups of metropolitan society, including those from the rural suburbs like Orunia. The GFIS became the key actor for consolidating the mature attitudes of the councilors of the then newly formed district council - the social advisory body of the city mayor. One of its main areas of activity entails improvement of the quality of the district's public space. Placemaking has become a tool to get people participating in community planning together, helping to mature local discussions about the future. The GUT team (led by the Second author) participated in this process since its very beginning, seeking cooperation in the long-run and applying the research-based design method. The cooperation-consolidating project of 2011, entitled: "17,000 sunflowers for Orunia," became the inspiration for the "Courtyard Revolution" project implemented by the GFIS in subsequent years, in cooperation with the City of Gdańsk and selected housing communities from Orunia (GFIS, 2013). The campaign, facilitated by the GFIS, mobilized the inhabitants to act as a neighborly self-help group. A kind of Orunian model of revitalization was developed, which has been proceeding owing to an alternative scenario - the strengthening of the grassroots self-organization, the building of internal and external bottom-up partnerships for the district, through implementation of self-help projects. Improvement of the spatial development of the backyards has developed into cooperation regarding other critical renovation issues, mainly related to the thermal modernization of the buildings. In this way, the solutions to synergistic problems, with the involvement of significant private financial resources, have been promoted.

In the following years of the R_LL's formation in Orunia, research and design studies were carried out, which examined the district's potential for the possibility of fusing two seemingly different concepts of city development - which would accelerate owing to the Smart City technological solutions (see Figure 8.5), with the Slow City model focused on balancing the pace of life. The concepts developed in the series "SlowSmartOrunia," which exploit ten different main problems including energy transition, became the source of an inspiring discussion, both among the local community and professionals. Showing the main features of the district, which were criticized or not perceived as assets, contributed to the progress in the involvement of the local community in the process of constructive participation for the renewal of their own living environment (Rembarz, 2019b).

The focus on the main potential of the district - the rural landscape and agricultural context - allowed presentation of the scale of the new possibilities in the shaping of the district's future, both in the placemaking solutions and in general microstrategic theses postulating the development of Orunia as a district of "renewable resources." The working planning hypotheses were visions that were ahead of the consciousness of the local authorities and the residents at that time, regarding the preservation of the district as a prototype of the metropolitan "slow suburbs" (Rembarz, 2018c, 2019a). The fusion of the agrihood model producing energy and healthy local food, in the spirit of the Milan Charter (Expo Milano, 2015) and the "Energy Improvement District" concept, creatively developed the country's routine revitalization assumptions. 


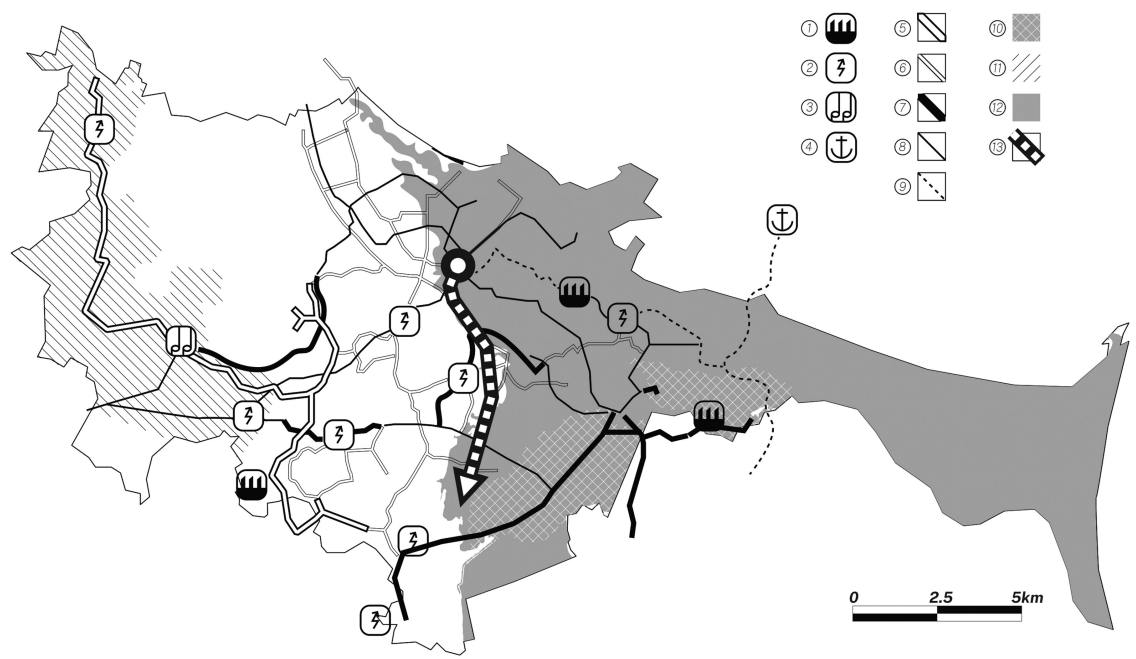

Figure 8.5 The City of Gdańsk counteracting climate change, records of commune-level planning studies (source: City of Gdańsk data, graphics J. Depczyk). Key: existing (6) district heating grid, (8) main high voltage line. Planned (1) combined heat and power plant, (2) transformer station, (3) pressure boosting station, (4) gas unloading station, (5) main heating station, (7) electric power line, (8) high pressure gas pipeline, (9) high voltage electricity lines, (10) RES equipment deployment zone, (11) district heat network development area, (12) area of flood risk due to the sea level rise.

The results of the research were submitted to the GFIS, district council and the Revitalization Department at the Municipal Office of Gdańsk, with the hope of using them, when updating the municipal policy in this area - mainly when formulating the assumptions of the district revitalization strategy. Due to the lack of a constructive interest in grassroots initiatives, on the part of the municipal services, the results of the R_LL II were used for preparation and implementation of the "Quo vadis, Gdańsk? The citizens are planning their district" project, financed by the Stefan Batory Foundation from the EEA fund through the program "Citizens for Democracy." Its main goal was to prepare the social side for conscious participation in official formats of socialization discussions regarding the future of the district. The Community Planning Academy started its activity, working in the format of urban mentoring, to formulate a microstrategy to improve the quality of the public space in the Gdańsk Orunia district (Martyniuk-Pęczek and Rembarz, 2016). The one-year workshop results, developed by a professional planning team became the document supporting the integration of the vision of the future of the Orunia region with its community representatives from the district council. The material officially submitted as an application, for the official municipal planning documents, was only partially processed by the municipal services. The revitalization plans developed under the regimes of modest budget and the legal framework that is unfavorable for comprehensive revitalization, 
directly used only selected threads of the microstrategy, implementing a classic (not risky and maximally economical) set of revitalization projects.

The main permanent effect of the cooperation with the local community is the development of local awareness, of both the local community representatives and the officials. Owing to this, the debate on the official city plans could be more constructive and secured against manipulation attempts. The revitalization plan from 2016 includes a clear vision exhibiting the agricultural identity and profile of the suburbs as well as including the possibility of joining the energy modernization of the municipal buildings located in the district, in the second phase of the process. ${ }^{17}$ The preliminary identification of the needs and the basic potentials in this respect, carried out as part of the revitalization activities, is a strong prerequisite for provision of the Energy Improvement District status for the Orunia district, in its second phase of revitalization. There is no doubt that the preparation of the local community (activists, councilors, representatives of communities and housing cooperatives) for substantive cooperation in this aspect of revitalization is much better than in other, often potentially socially stronger districts of the city.

The revitalization planned provides an excellent opportunity to include the activities related to energy transition measures. These may be based to introduce experience gained in R_LL. First action includes recognizing the opportunities and weaknesses of the district in relation to attainable energy/heat resources. The Gdańsk district heating (DH) grid reaches Orunia and presents the opportunity to develop a fourth generation $\mathrm{DH}$ system using the low temperature heat from return flux. Low temperature $\mathrm{DH}$ grid presents a series of advantages, which include:

- Reduction of heat losses in DH pipes;

- Enabling easy inclusion of other RES e.g., solar thermal collectors, geothermal sources, etc.;

- Easy integration of low temperature waste/surplus heat;

- Reduction of thermal stress in grid pipes and prolonged DH-grid life;

- Lower return flux temperature, which enables its application for flue gas condensation in Combined Heat and Power (CHP) plant.

Where the Gdańsk DH grid is absent (due to economic reasons) one may consider replacement of traditional coal burners with renewable alternatives, such as biomass systems or heat pumps powered by the electricity produced in a prosumer regime.

\section{Revitalization: Living Labs - lessons learned}

It should be underlined that the role of a bottom-up approach is crucial in the Polish setting: from local activists, scientists to entrepreneurs, who acknowledge the need for energy transition, which cannot be ignored, considering the growing population, its energy needs and the depletion of fossil fuels.

The experience gained over a decade, owing to the participation in the development of the R_LLs in Lubań and Gdańsk-Orunia, allows for a diagnosis of the phases characterizing the process of social awareness change, taking into account 
the issues of energy transition implemented in the context of revitalization. There is a clear shift from a reasoning characterized by traditional renovation criteria, through a modernization approach, to the vision of a fundamental change at the technological level. This process takes place in a strong social context, in which the prevailing attitude of hopelessness and a lack of crisis-overcoming concepts, evolves, thanks to the participatory process, into a constructive state of cooperation, which allows for effective use of the available financial aid programs. In each phase of this peculiar evolution, the search for alternative solutions, both technological and organizational, constituted the fundamental assumption. The activation of the social energy was one of the main factors determining the activation and the duration of the state of change. In order to be able to tap into this endogenous resource, social trust needs to be gained, developed in a stable, staged process of dialogue and cooperation. Full implementation of the revitalization and energy transformation objectives means a permanent, constructive change in the lifestyle of the local community.

The R_LL I in Lubań has extended the Living Lab's technical format which was dedicated to energy issues, by including additional dimensions which are typical for comprehensive revitalization. A simple administrative decision to adapt the buildings of an agricultural school as a regional agricultural advisory center, owing to the cooperation with academic centers, the established partnerships with the local business and the socialization, has turned into a vision of a model solution promoting rural development in a multi-faceted manner. In addition to the gaining of social trust and the selection of reliable partners to the transformation, an environmental change took place in the culture of cooperation based on a transfer of knowledge.

In Lubań-sized rural centers and the local managing municipalities (Nowa Karczma), the gaining of social trust is expressed more clearly than in large-city centers. The R_LL I shows that the public partner, by providing long-perspective support for the project, has reflected as well as strengthened the positive social assessment. The success of the local agreement worked out has also become an argument favoring the strengthening of the supra-local function in Luban and the expanding of the revitalization vision. The durability of involvement in the project, on the part of the public partner representing the supra-local level, has become the guarantee of continuation and transition to the next level of development.

The R_LL II in Gdańsk-Orunia brings into attention the fact that this format, more than the R_LL I, has been an observation of the process rather than a project implementation. R_LL II is an example of format expansion, from a Social Innovation Living Lab, broadening its activity through social and spatial projects that facilitate the development of multi-faceted revitalization. The GFIS organization's activity in the environment of a deprived district, using the potential of cooperation with an academic center, has again indicated that revitalization is an integrated process. The district dialogue about space, which had been years ahead of the city's activity, was based on the assumption of knowledge expansion and harmonization. It was not so much about designing a specific vision of 
development and gaining support for it, but about preparing the local community and its representatives - activists, district and city councilors - for constructive cooperation, as part of the municipal renovation and revitalization processes. The cooperation between GFIS and GUT translated, firstly, into an intra-district dialogue, moderated via a local social network; secondly, into the strengthening of the district's position in the municipal authorities' policy and administration; and thirdly, into the building of the district's new image, so as to break away from its stigmatizing external perception. Transition to the next stage of revitalization will require access to financial programs dedicated to energy transformation, and therefore it will change the argumentation and the narrative used in the dialogue with the city administration. In terms of the R_LL II, this may mean cooperation regarding the launch of Living Lab projects testing the possibilities of new technological solutions. Their presence in the local community environment being prepared for cooperation has the potential to strengthen the achievement of synergistic effects.

Both private entities (small business) as well as communities operating with the support of local NGOs can be partners in the cooperation aimed at energy transformation, the primary goal of which is to increase the quality and the public "benefits." Nevertheless, both R_LLs affirm that the sense of social mission, shared by both the initiators and the broadly understood transformation facilitators, is the key factor in the achievement of a lasting socio-technical development change. It shapes the nature of the involvement of the partners in the transformation as well as the understanding of the multi-faceted vision organizing the process. The R_LL I and II provide the experience illustrating the scale of unrealized potential due to the lack of a habit of cooperation between public administration and academic centers. The lack of trust that exists here often leads to a wastage associated with the loss of the synergistic effects arising from the integration of knowledge and the acting with awareness of the pursuit for complexity in modernization activities. Academic centers have the competences and resources that go beyond the scope of the routine activities of municipal offices, not only in small centers. In addition to the strictly technological innovations, they gather and disseminate the organizational knowledge enabling activity aimed at initiation of innovative solutions in an alternative manner, independent of the current political trends and administrative habits.

\section{Conclusions}

Over 45 years of socialistic regime left Poland in great need of reforms and revitalization of neglected regions. Moreover, revitalization has not been the focus of the new liberal government. The new liberal policy also limited the role of local administration in supporting the rejuvenation activities. So, the citizens of degraded and forgotten municipalities and regions, alienated and left alone with life-critical problems, acquired negative and critical relations towards most of the authorities and their new ideas. In order to implement the energy transition measures one needs to address the issue of how to renew 
dissipated social capital and to involve the citizens in the revitalization of their own region.

As a metropolitan area located along the Gdańsk Bay, still constituting a coherent organism, the union of OMGGS has been gradually striving to establish a sufficiently strong platform for cooperation in the midst of unfavorable development trends. The slogan Smart City (Smart Metropolis) is a key element in the debate taking place under the shadow of the dynamic reality, inscribed in the global economy of speculative investments, concentrated in the core of the metropolitan area (Bisello et al., 2018). The experiences of the projects represented by the above-described examples of the R_LL in Lubań and in Gdańsk-Orunia can serve as examples of pilot solutions - important from the perspective of semirural and rural communes, both in the OMGGS and the entire Pomeranian Region. The key aspect here is to show not only the technical and organizational solutions, but to indicate the political barriers to cooperation that must be overcome between the public parties to the issue (the government) and the social (local community) party, which initiates a change both from the perspective of pure non-profit activism or as a model with the features of an entrepreneurship incubator. In the activity under the cooperation developed here via the R_LL format regarding the issues of energy transition greater potential for effective financial assembly, within the PPP framework, is made possible.

Development of a formula for cooperation within the informal R_LL allowed the development of results which, owing to the scientific publications, led to the expansion of the interdisciplinarity of the team cooperating, unconventionally connecting energy specialists with urban planners (in Poland). The comparison and combination of the experiences promise possible use of the hitherto developed R_LL research practices at the next stage of implementation research. Initial talks with the city authorities regarding the possibility of taking the next step towards the implementation of an energy-sufficient model of a SlowSmartSuburb in Orunia are ongoing. The role of a bottom-up approach in the Polish setting should be stressed: from local activists, scientists to young entrepreneurs, who are convinced about the need for energy transition, which cannot be ignored taking into account a growing population, its energy needs and depletion of fossil fuels.

The experience gained from the cooperation within the R_LL I and II highlights a number of systemic deficiencies in conducting revitalization processes, the most important of which include:

1. Ineffective mechanisms of cooperation between the public sector, the civicsocial and business-social initiatives concerning spatial and organizational innovation;

2. Ineffective legal and financial instruments inhibiting the development of integrated planning and the implementation at the interface of the public (municipal) and the private sectors, including PPP;

3. A perceivable stratification between the declarative implementation of farreaching EU development priorities and the real everyday needs associated with the unfinished convergence of quality and standards; 
4. Underestimation of the time factor in the planning of urban processes and in the introduced sudden and unprepared changes generated by ad hoc initiatives and political decisions - priority for implementation activities that have been insufficiently recognized in analytical and planning studies;

5. Lack of experience in the generation of innovation derived from the balance of successes and failures rather than the sum of successes. Local-level innovation cannot be limited to the adaptation of foreign solutions to the local conditions.

\section{Notes}

1 www.ftserussell.com.

2 www.definitions.net/definition/revitalisation.

3 https:/dictionary.cambride.org/dictionary/english/revitalization.

4 In operation since February 2015; for more see: polskialarmsmogowy.pl.

5 European Air Quality Index.

6 The so-called anti-smog resolutions, i.e., Plans for Low-Emission Economy, more broadly the 2020 Climate Change Adaptation Plans, with a perspective of implementation by 2030, have been drawn up by municipalities since 2015 .

7 https://eur-lex.europa.eu/legal-content/en/ALL/?uri=CELEX:32008L0050.

8 Alior Bank, BNP Paribas Bank Polska, Bank Ochrony Środowiska, Bank Pocztowy, Bank Polskiej Spółdzielczości, Credit Agricole Bank Polska, Santander Consumer Bank and Bank Spółdzielczy SGB https://czystepowietrze.gov.pl/.

9 The Revitalization Act of 2015 Article 2.1-2.

10 It should be remembered that the family small and micro enterprises, fundamentally associated with the local community, constitute a significant part of the Polish economy (Martyniuk-Pęczek et al., 2020).

11 The method of working in the real user's environment (in situ), represented in the applications of the Living Lab model, is crucial in technical and engineering sciences. However, the concept itself is currently closely associated with the development of digital technology applications, mainly in connection with the work of MIT (Westerlund et al., 2018). LL has become the main instrument for the practical implementation of the demand-driven approach to innovation in the field of IT applications (Rembarz, 2018b).

12 https://enoll.org/.

13 JPI Urban Europe Project, 2013-2016.

14 http://gfis.pl/.

15 https://eia.pg.edu.pl/linte/main.

16 https://southbaltic.eu/-/wasteman.

17 City of Gdańsk revitalization program was started in 2016 and approved in 2017 as a strategic document addressed to four problem areas of historical districts with complex social issues - Orunia is one of them.

\section{References}

Bergvall-Kåreborn, B., Ståhlbröst, A. (2009). Living lab: An open and citizen-centric approach for innovation. International Journal of Innovation and Regional Development, 1(4), pp. 356-70. Geneva: Inderscience Publishers. DOI:10.1504/IJIRD.2009.022727 
Bevilacqua, C., Pizzimenti, P. (2016). Living lab and cities as smart specialization strategies engine. Procedia-Social and Behavioral Sciences, 223, pp. 915-22. Amsterdam: Elsevier. DOI:10.1016/j.sbspro.2016.05.315

Bisello, A., Vettorato, D., Laconte, P., Costa, S. (Eds). (2018). Smart and sustainable planning for cities and regions. Results of SSPCR 2017. Eurac Research, Springer, series: Green Energy and Technology. Berlin: Springer Science+Business Media.

Bujakowski, W. (2010). The use of geothermal waters in Poland (state in 2009). Przegląd Geologiczny, 58(7), pp. 580-8. Warsaw: PIG-PIB.

Cardullo, P., Kitchin, R., Di Feliciantonio, C. (2018). Living labs and vacancy in the neoliberal city. Cities, 73, pp. 44-50. Amsterdam: Elsevier.

CBOS. (2020). Zaufanie Społeczne, Komunikat z Badań Nr 43/2020 [Social trust, communication from research no 43/2020]. CBOS. Online: https://www.cbos.pl/ SPISKOM.POL/2020/K_043_20.PDF (Accessed on: 24.07.2021).

Cenian, A., Lampart, P., Kiciński, J. (2015a). Eco-innovative technologies for sustainable energetics developed in IMP PAN Gdańsk, Part 1. Przegląd Energetyczny, 79, pp. 36-9. Warsaw: Izba Gospodarcza Energetyki i Ochrony Środowiska.

Cenian, A., Lampart, P., Kiciński, J., (Eds). (2015b). Technologies and devices for distributed sustainable energetics based on biomass and agrowastes. Gdańsk: IMP PAN Publishers.

Cenian, A., Dzierzgowski, M., Pietrzykowski, B. (2019). On the road to low temperature district heating. Journal of Physics: Conference Series, 1398, p. 012002. Bristol: IOP Publishing. DOI:10.1088/1742-6596/1398/1/012002

Czechowicz, M. (2021). Mój Prąd 3.0 od 1 lipca 2021. Jakie nowe możliwości daje program Mój Prąd 3.0? Jaka będzie dotacja? [Mój Prąd 3.0 from 1 July 2021. Which new possibilities gives program Mój Prąd 3.0? What subsidy is to be expected?] Online: https://www.muratorplus.pl/biznes/prawo/moj-prad-3-0-od-1-lipca-jakie-nowe -mozliwosci-daje-program-moj-prad-3-0-przygotowany-na-2021-aa-stDW-mAUk -qLHS.html (Accessed on: 24.07.2021).

Duda, J., Cenian, A. (2013). Method and a device for the combined production of electricity from the waste heat from the kiln and the gas produced in reactor technology associated with the cyclone heat exchanger, PL Patent PL222866B1. Online: https://worldwide.espacenet .com/patent/search/family/051588927/publication/PL222866B1?q=PL222866B1 (Accessed on: 24.07.2021).

Dudyński, M., Kwiatkowski, K., Bajer, K. (2012). From feathers to syngas - Technologies and devices. Waste Management, 32, pp. 685-91. Amsterdam: Elsevier. DOI:10.1016/j. wasman.2011.11.017

Dworakowska, M. (2018). Dochody budżetowe jednostek samorządu terytorialnego z perspektywy absorpcji funduszy unijnych [Budget income of local self-governments from the perspective of EU funds absorption] Optimum. Economic Studies, 3(93), pp. 51-62. Białystok: Wydawnictwo Uniwersytetu w Białymstoku. DOI:10.15290/ oes.2018.03.93.05

Dziemianowicz, W., Szlachta, J. (Eds). (2016). The value chain of a commune. Warsaw: Studia KPZK PAN, p. 169.

ESCO. (2017). Online: https://www.escowpolsce.pl/aktualnosci/modernizacja-25 -budynkow-w-sopocie-za-ponad-215-mln-zl.html (Accessed on: 24.07.2021).

Expo Milano. (2015). Expo Milano 2015 - Official report. Milan: Expo 2015 S.p.A. Online: https://issuu.com/expomilano2015/docs/expo-milano-2015_official-report_en (Accessed on: 11.08.2021).

Feofilovs, M., Pakere, I., Romagnoli, F. (2019). Life cycle assessment of different lowtemperature district heating development scenarios: A case study of municipality in 
Latvia. Environmental and Climate Technologies, 23(2), pp. 272-90. Warsaw: Sceindo. DOI:10.2478/rtuect-2019-0068

Fischer, J., Arlati, A., Johst, J., Vladova, G., Knieling, J., Camara, C. (2020). Energy improvement districts: Conceptual and technical guidance for implementing cooperative energy planning at the district level. Hamburg: HafenCity Universität Hamburg.

GFIS Gdańska Fundacja Innowacji Społecznej. (2013). Przewodnik po podwórkach - czyli jak w 10 krokach zmienić wspólnie z mieszkańcami przestrzeń ich sąsiedztwa [Guide through courtyards - or how to change with citizens their neighborhood in 10 steps]. Online: http://gfis.pl/wp-content/uploads/2013/07/model-podworka.pdf (Accessed on: 24.07.2021).

Jadach-Sepioło, A., Kułaczkowska, A., Mróz, A. (Eds). (2018). Rewitalizacja w praktyce. Modele rozwiązań jako rezultaty konkursu Modelowa Rewitalizacja Miast i pilotaży w zakresie rewitalizacji [Revitalisation in practise. Model solutions as results of competition 'Model Cities Revitalisation and pilots in the field of revitalisation']. Kraków: Krajowy Instytut Polityki Przestrzennej i Mieszkalnictwa.

Konkol, I., Cebula, J., Cenian, A. (2020). Oxidization of hydrogen sulfide in biogas by manganese (IV) oxide particles. Environmental Engineering Research, 26(2), p. 190343. Seoul: KSEE. DOI:10.4491/eer.2019.343

Krug, M., Rabczuk, G., Cenian, A. (2015). Addressing sustainability risks of bioenergyPolicy strategies and corporate initiatives. Energy and Power Engineering, 7(5), pp. 217241. Wuhan: Scientific Research Publishing. DOI:10.4236/epe.2015.75022

Martyniuk-Pęczek, J., Rembarz, G. (2016). The urban mentoring as a new method of participatory urban planning in Poland. Procedia Engineering, 161, pp. 1647-55. Amsterdam: Elsevier. DOI:10.1016/j.proeng.2016.08.640

Martyniuk-Pęczek, J., Parteka, T., Martyniuk, O. (2020). Entrepreneurship nests in a Polish Edge City. Gdańsk: Wydawnictwo PG.

Najwyższa Izba Kontroli NIK. (2017). Informacja o wynikach kontroli. System gospodarowania przestrzenią gminy jako dobrem publicznym. Zbiorcze zestawienie kontroli przeprowadzonych przez Najwyższą Izbę Kontroli pod kątem gospodarowania przestrzenią [Information on results of verification. System for management of municipal space as a public good. Summary of the inspections carried out by the Supreme Audit Office in respect to space management]. Online: https://www.nik.gov.pl/aktualnosci /nik-o-systemie-gospodarowania-przestrzenia-gmin.html (Accessed on: 24.07.2021).

NFOŚiGW. (2021). Osiem banków zgłosiło się do programu "Czyste Powietrze" [Eight banks joined the program "Clean Air"]. Online: https://czystepowietrze.gov.pl/osiem -bankow-zglosilo-sie-do-programu-czyste-powietrze (Accessed on: 24.07.2021).

Orłowski, W. M. (2013). Komercjalizacja badań naukowych w Polsce. Bariery i możliwości ich przetamania [Commercialization of scientific research in Poland. Barriers and the possibility to breake them]. Warsawa: $\mathrm{PwC}$.

Pająk, L., Tomaszewska, B., Bujakowski, W., Bielec, B., Dendys, M. (2020). Review of the low-enthalpy lower cretaceous geothermal energy resources in Poland as an environmentally friendly source of heat for urban district heating systems. Energies, 13, p. 1302. Basel: MDPI. DOI:10.3390/en13061302

Pakere, I., Romagnoli, F., Blumberga, D. (2018). Introduction of small-scale 4th generation district heating system. Methodology approach. Energy Procedia, 149, pp. 549-54. Amsterdam: Elsevier. DOI:10.1016/j.egypro.2018.08.219

Portal Komunalny. (2021). Kurtyka: 80 proc. gmin chce uczestniczyć w programie "Czyste Powietrze" [Kurtyka: $80 \%$ of communes want to participate in program "Clean Air"]. 
Online: https://portalkomunalny.pl/kurtyka-80-proc-gmin-chce-uczestniczyc-w -programie-czyste-powietrze-417279/ (Accessed on: 24.07.2021).

Przywojska, J. (2016). Rewitalizacja miast. Aspekt społeczny [City revitalisation. Social aspect]. Akademia Samorzadowa. Lodz: Lodz University Press.

Rembarz, G. (2018a). Urban innovation in the context of shaping the residential environment. In G. Rembarz (Ed.), Beauty and energy: A contemporary model for development of new residential areas/districs in Europe, pp. 96-129. Warsaw: Studia KPZK PAN.

Rembarz, G. (2018b). Revitalization: Living lab as a method to generate and implement innovation towards renewal in smart city on case of Gdańsk-Orunia District. In P. Lorens (Ed.), Urban aspects of cities' transformation, pp. 192-209. Warsaw: Studia KPZK PAN.

Rembarz, G. (2018c). The agri-hood and slow-suburb concept in the context of an in-between city (Zwischenstadt). In 5th International Multidisciplinary Scientific Conference on Social Sciences and Arts SGEM 2018, 18, pp. 519-26. Sofia: STEF92 Technology Ltd. DOI:10.5593/sgemsocial2018/5.2/S20.065

Rembarz, G. (2018d). Gdańsk-Orunia as a living lab for innovation in revitalization. In 5th International Multidisciplinary Scientific Conference on Social Sciences and Arts SGEM 2018, 18, pp. 391-8. Sofia: STEF92 Technology Ltd. DOI:10.5593/sgemsocial2018/5.2/ S20.049

Rembarz, G. (2019a). Koncepcja metropolitalnego slow-przedmieścia jako narzędzie poprawy jakości życia w międzymieście [Concept of metropolitan slow-suberbs as a tool to improved life quality in intercity]. Public Management, 1(45), pp. 19-34, Krakow: Zarządzanie Publiczne. DOI:10.4467/20843968ZP.19.002.9943

Rembarz, G. (2019b). The potential of urban agriculture in the revitalisation of a metropolis. In A. Đukić, A. Krstic-Furundzic, E. Vanista Lazarevic (Eds), Keeping $u$ p with technologies to create the cognitive city, pp. 356-71. Newcastle: Cambridge Scholars Publishing.

Revitalization Act. (2015). (PL). Online: http://isap.sejm.gov.pl/isap.nsf/download.xsp/ WDU20150001777/U/D20151777Lj.pdf (Accessed on: 24.07.2021).

Sejmik Województwa Pomorskiego. (2021). Uchwała nr 376/XXXI/21 z dnia12 kwietnia 2021 roku w sprawie uchwalenia Strategii Rozwoju Województwa Pomorskiego 2030 [Resolution No. 376/ XXXI/21 of April 12, 2021 on the adoption of Development Strategy for the Pomeranian Voivodeship 2030]. Online: https://pomorskie.eu/wp -content/uploads/2021/04/Za\%C5\%82\%C4\%85cznik-do-uchwa\%C5\%82y_SWP _376_XXXI_21_SRWP2030_120421.pdf (Accessed on: 24.07.2021).

Sokołowski, J., Zelewski, D., Joanna Stępień, J., Lewandowski, P. (2021). Energy poverty between energy paradigms in Poland. In G. Jiglau, A. Sinea, U. Dubois, P. Biermann (Eds), Perspectives on energy poverty in post-communist Europe, pp. 139-52. Abingdon: Routledge. DOI:10.4324/9781003000976

Sześciło, D. (2019). Polska samorządów. Silna demokracja, skuteczne państwo [Poland of self-governments. Strong democracy, effective state]. Warzaw: Fundacja im. Stefana Batorego.

Sztompka, P. (1996). Trust and emerging democracy: Lessons from Poland. International Sociology, 11(1), pp. 37-62. Thousand Oaks: SAGE Publishing. DOI:10.1177/026858096011001004

Tang, L. Y., Shen, Q., Cheng, E. W. L. (2010). A review of studies on publicprivate partnership projects in the construction industry. International Journal of Project Management, 28, pp. 683-94. Amsterdam: Elsevier. DOI:10.1016/j. ijproman.2009.11.009 
184 Bartosz Pietrzykowski et al.

United Nations Human Settlements Programme (UN-Habitat). (2016). Urban planning and design labs tools for integrated and participatory urban planning. HS Number: HS/060/16E. Online: https://unhabitat.org/books/urban-planning-and-design-labs -tools-for-integrated-and-participatory-urban-planning/ (Accessed on: 24.07.2021).

Urząd Gminy Nowa Karczma. (2020). Raport o stanie Gminy Nowa Karczma za 2020 rok [Report on Nowa Karczma municipality condition]. Online: https://nowakarczma .biuletyn.net/fls/bip_pliki/2021_05/BIPF5C36043ACA351Z/Raport_2020.pdf (Accessed on: 24.07.2021).

Wallin, S. (2014). APRILab: Guidelines to define and establish an urban living lab. Amsterdam: Amsterdam Institute of Social Science Research.

Westerlund, M., Leminen, S., Habib, C. (2018). Key constructs and a definition of living labs as innovation platforms. Technology Innovation Management Review, 8(12), pp. 51-62. Ottawa: Carleton University. DOI:10.22215/timreview/1205

Wis-Bielewicz, J., Koziarek, M., Olesińska, J., Owczarek, D., Lisa Schneider, L., Serre, C. (2018). Efektywna energetycznie rewitalizacja kluczem do poprawy jakości życia w polskich miastach [Effective energetic revitalization as a key to improved life quality in polish cities]. Warsaw and Berlin: Adelphi Research. 